Article

\title{
Biodiversity of Entomopathogenic Fungi in the Soils of South China
}

\author{
Xiaoyan $\mathrm{Niu}^{\dagger}{ }^{\dagger}$, Weiwen $\mathrm{Xie}^{\dagger}{ }^{\dagger}$, Jing Zhang ${ }^{\dagger}$ and Qiongbo $\mathrm{Hu}{ }^{*} \mathbb{C}$ \\ Key Laboratory of Bio-Pesticide Innovation and Application of Guangdong Province, College of Agriculture, \\ South China Agricultural University, Guangzhou 510642, China \\ * Correspondence: hqbscau@scau.edu.cn \\ t These authors contributed equally to this work.
}

Received: 6 July 2019; Accepted: 29 August 2019; Published: 3 September 2019

\begin{abstract}
The southern part of China, located in tropical and south subtropical areas has unique natural environments, but the distributions of entomopathogenic fungi (EFs) in the soil are not clear. In this research, 198 soil samples were collected from the four Provinces (Autonomous Region) of South China. The results indicated that a total of 292 fungal isolates were obtained from 176 soil samples. Then, based on the morphological and rDNA-ITS sequences analysis, $213 \mathrm{EFs}$ isolates of 19 species in 12 genera were identified. Furthermore, Purpureocillium lilacinum with 75 isolates was recognized as the absolutely dominant EF species, while Isaria javanica, Metarhizium anisopliae, and Beauveria bassiana (respectively with 29, 26, and 26 isolates) were the richer species. The data also indicated that Guangxi Province has the best EFs diversity with the Shannon-Wiener index (SWI) of 2.29, the soils covered with grass had the best EFs diversity with the 2.14 SWI, while the orchard and fallow land had the lowest SWI of 1.52, which suggested that the diversity of plants and insects on ground, as well as the massive application of broad-spectrum fungicides, affect the EFs diversity in the soil. Finally, the rare species, Nectria mauritiicola and Scopulariopsis brumptii were first reported about their entomopathogenic activities against Bemisia tabaci. Our experiment will give new insights to the understanding of EFs distribution characteristics and their biodiversity conservation.
\end{abstract}

Keywords: entomopathogenic fungi; soil; biodiversity; bioactivity; whitefly

\section{Introduction}

Entomopathogenic fungi (EFs), a kind of important pathogens infecting host insects (arthropods), play key roles in the regulation of insect populations and biotransformation in natural biosystems. Differing from the bacteria and virus pathogens infecting insects through mouthparts and guts, EFs invade insects through the cuticles [1]. The popular EFs, Beauveria bassiana, Metarhizium anisopliae, Purpureocillium lilacinum, and Isaria fumosorosea, etc., have been developing as mycopesticides to control agricultural, forest, and disease vectors pests such as locusts, grubs, aphids, whiteflies, moths, mosquitoes, and phytopathogenic nematodes, etc. [2,3]. On the other hand, a lot of EFs such as Cordyceps spp. are expensive edible and medical mushrooms and have been used for traditional health foods and medicines in East Asia [4,5]. Additionally, EFs produce multiple secondary metabolites with some bioactivities and functions, which have the potencies for medicines or nutriments [6]. However, according to the report of 'State of the World's Fungi 2018', the natural EFs resources are declining, for example, the annual yield of the Chinese caterpillar fungus (Ophiocordyceps sinensis) had declined from more than 100 tonnes in the 1950s to 5-15 tonnes in the 1990s [7]. Obviously, it is urgent to conserve the EFs resources.

Most EFs are soil-dwelled microbes. Soil provides a destination for insect fungal diseases and a surrounding for the EFs rhizosphere, but the soil conditions such as the temperatures, moistures, 
pHs, and microbes influence the EFs persistence and survival [8-10]. For example, B. bassiana, M. anisopliae, and M. pingshaense can persist and survive in soil for long times, but they are closely affected by nutritional, microbial, and physiochemical factors of the soil. Additionally, in fact, EFs have proliferation in the soil with enough nutrition [11-14]. Moreover, the residues of pesticides and heavy metals affect the soil microbial activities and fungal community structures [15,16]. However, the statuses of EFs in soil stages are not well understood by researchers. Investigating the soil EFs will be beneficial to the discovery of new species and conservation of EFs resources [17,18]. Meanwhile, in order to better recognize the mechanisms of occurrences and the storage of EFs, it is necessary to investigate the soil EFs [19].

South China is located in the tropic and south subtropical areas with hot, moisture, rainy climatic, acidic soils and multiple vegetation, which is a center with abundant biodiversity [20]. Moreover, South China is a district of unbalanced economic development, for example, the areas of Pearl River Delta belong to the developed industrial district having a heavier environmental pollution and ecological safety of exotic species, while the remote mountainous areas of Guangxi, Guizhou, and Yunnan Provinces belong to the under-developing or poor regions with better natural environments [21]. However, the distribution of soil EFs in these areas are not clear. Therefore, the purpose of this research is to investigate the EFs distribution and abundance in different soil habits in South China areas including the provinces (Autonomous Region) of Fujian, Guangdong, Hainan, Guangxi, Yunnan, and Guizhou. Then, it is intended to analyze and discuss the influences of human activities and environment changes on the EFs. The research will give some new insights to the EFs biodiversity and their distribution characterization.

\section{Materials and Methods}

\subsection{Soil Sample Collection}

The soil samples were collected from the location sites with various types of covered plants including crop lands (farming lands covered with crops such as grains, tomatoes, vegetables, etc.), fallow lands (farming lands but no crops growing), forests (the lands covered with forests except eucalyptus trees), grasses (the lands covered with grasses) and eucalyptus forests (the lands covered with eucalyptus trees). The longitude and latitude in each site were recorded by ICEGPS 100C (Shenzhen, China). From each site, approximately $200 \mathrm{~g}$ of soil beneath the ground $10-15 \mathrm{~cm}$ in three randomly selected points were collected and mixed as a sample stored in a plastic bag at $4{ }^{\circ} \mathrm{C}$ for further use. The total 198 samples were collected from 170 sites in four provinces including Fujian, Guangdong, Guangxi, and Hainan in South China (Figure 1).

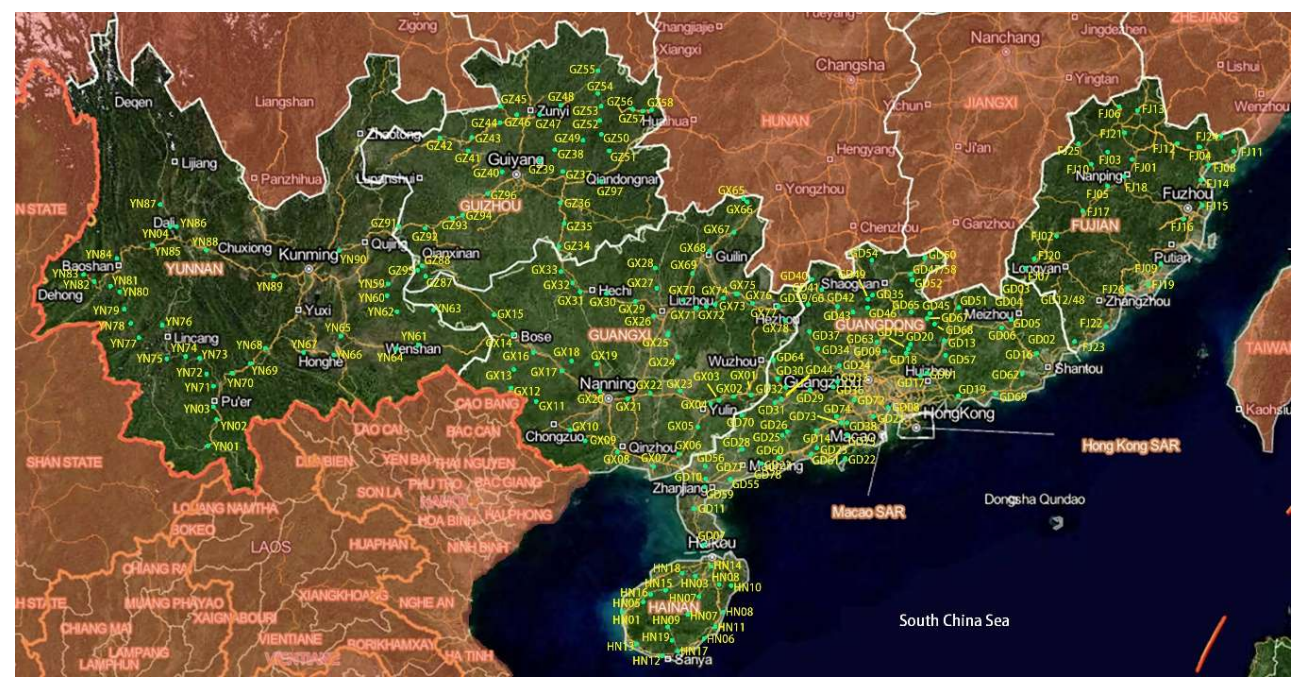

Figure 1. The map of sites distribution for the soil samples collection. 


\subsection{Isolation of Fungal Species from the Soil Samples}

The method of our previous experiment [8] was referred to the isolate fungal strains from the soil samples. Totally, the samples were pre-treated to remove stones and plants residues, then the soil suspensions of $0.02 \mathrm{~g} / \mathrm{mL}$ were prepared with the $0.1 \%$ Tween- 80 solution. The $0.1 \mathrm{~mL}$ suspension was inoculated onto a selective medium plate (when PDA $1000 \mathrm{~mL}$ was cooled to $50{ }^{\circ} \mathrm{C}, 0.2 \mathrm{~g}$ cycloheximide, $0.2 \mathrm{~g}$ chloramphenicol, and $0.0133 \mathrm{~g}$ rose Bengal sodium were added) and the fungal colonies were picked out to PDA plates for culture and further uses [22]. Each sample was subjected to fungal isolation two times.

\subsection{Identification of Fungal Species and Analysis of Genetic Homology}

The identification of fungal isolates was based on the morphological characteristics and similarity of the rDNA-ITS sequences. The method of our previous experiment [8] was referred. In summary, an optical microscope system equipped with a digital camera (MC-D500U, Phenix, Jiangxi, China) was employed to carry on the morphological analysis to measure the mycelia, conidia, and sporulation structures of fungal isolates. The DNA extraction kits (DP3112, Bio-Teke, Beijing, China) were used to extract the total DNA from fungal isolates. The primers ITS1 (5'-TCCGTAGGTGAACCTGCGG-3') and ITS4 (5'-TCCTCCGCTTATTGATATGC-3') were used to amplify the fungal ITS regions with the standard PCR cycling protocol on the T100 ${ }^{\mathrm{TM}}$ Thermal Cycler (BIO-RAD, USA). The PCR products were visualized with UV illumination and photographed (Tanon-1600, Tanon, Shanghai, China) and sequenced by Sangon Biotech on an ABI-PRISM3730 automated sequencer (Applied Biosystems, USA). The obtained rDNA-ITS sequences were submitted on a GenBank and compared with similar sequences through the BLAST of NCBI. The phylogenetic trees of the EFs were constructed by MEGA X [23] with a statistical method of maximum likelihood, a bootstrap test of 500 replications, and the Jukes-Cantor model. The standard EF strains were referred (Table 1).

Table 1. The information of the referred fungal strains.

\begin{tabular}{|c|c|c|c|}
\hline Species/Strain & GenBank Accession Number & Geographic Origin & Ref. \\
\hline Beauveria bassiana ARSEF 8187 & HQ444271 & Canada & [24] \\
\hline Beauveria bassiana CBS 465.70 & MH859798 & Israel & [25] \\
\hline Beauveria bassiana CBS 110.25 & MH854802 & Sri Lanka & [25] \\
\hline Cephalotrichum microsporum CBS 127792 & MH864708 & USA & [25] \\
\hline Clonostachys rosea CBS 127881 & MH864739 & Spain & [25] \\
\hline Cordyceps cateniannulata CBS 152.83 & NR_111169 & Thailand & [26] \\
\hline Isaria cateniannulata ARSEF 6242 & GU734760 & Brazil & [27] \\
\hline Isaria farinosa ARSEF 4029 & HQ880828 & Denmark & [28] \\
\hline Isaria farinosa CBS 262.58 & AY624179 & Thailand & [29] \\
\hline Isaria fumosorosea ARSEF 887 & EU553334 & Brazil & [30] \\
\hline Isaria fumosorosea CBS 244.31 & AY624182 & Thailand & [29] \\
\hline Isaria javanica CBS 134.22 & DQ403723 & USA & [31] \\
\hline Isaria javanica CHE-CNRCB 303/2 & KM234213 & Mexico & [32] \\
\hline Lecanicillium psalliotae CBS 532.81 & JN049846 & USA & [33] \\
\hline Metarhizium anisopliae ARSEF 488 & FJ609303 & Philippines & [34] \\
\hline Metarhizium anisopliae CBS 657.67 & MH859066 & New Caledonia & [25] \\
\hline Metarhizium flavoviride CBS 218.56 & MH857590 & Czech & [25] \\
\hline Metarhizium flavoviride var. flavoviride ARSEF 2024 & AF138268 & Australia & [35] \\
\hline Metarhizium marquandii CBS 282.53 & MH857200 & UK & [25] \\
\hline Metarhizium marquandii CBS 130230 & MH865781 & USA & [25] \\
\hline Metapochonia bulbillosa 38G272 & EU999952 & Costa Rica & [36] \\
\hline Metapochonia bulbillosa CBS 145.70 & AJ292397 & UK & [37] \\
\hline Metapochonia bulbillosa FKI-4395 & AB709836 & Japan & [38] \\
\hline Nectria mauritiicola P288_D1_21 & JF311964 & Canada & [39] \\
\hline Paecilomyces carneus CBS 399.59 & AY624170 & Thailand & [29] \\
\hline Paecilomyces carneus CG 525 & EU553292 & Brazil & [30] \\
\hline Paecilomyces marquandii G28 & GU566261 & Czech & [40] \\
\hline Paecilomyces variotii CBS 338.51 & FJ389930 & Netherlands & [41] \\
\hline Penicillium citrinum CBS 117.64 & MH858380 & Netherlands & [25] \\
\hline
\end{tabular}


Table 1. Cont.

\begin{tabular}{llll}
\hline Species/Strain & GenBank Accession Number & Geographic Origin & Ref. \\
\hline Phialophora verrucosa CBS 286.47 & KF928455 & Netherlands & {$[42]$} \\
Pochonia chlamydosporia var. catenulata CBS 504.66 & MH858871 & Canada & {$[25]$} \\
Pochonia chlamydosporia CBS 103.65 & AJ292397 & UK & {$[37]$} \\
Pochonia chlamydosporia CBS 429.64 & MH858477 & Brazil & {$[25]$} \\
Purpureocillium lilacinum ATT161 & HQ607867 & USA & {$[43]$} \\
Purpureocillium lilacinum CBS284.36 & NR_111432 & Spain & {$[26]$} \\
Purpureocillium lilacinum NRRL 6453 & HQ842836 & Netherlands. & {$[44]$} \\
Schizophyllum commune CBS 124811 & MH863418 & Netherlands & {$[25]$} \\
Scopulariopsis brumptii CBS 121662 & LN850803 & USA & {$[45]$} \\
Simplicillium lanosoniveum CBS 531.72 & MH860557 & USA & {$[25]$} \\
Talaromyces pinophilus CBS 631.66 & NR_111691 & Netherlands & {$[26]$} \\
Umbelopsis dimorpha CBS 110039 & KC489478 & New Zealand & {$[46]$} \\
\hline
\end{tabular}

\subsection{Evaluation of Shannon-Wiener Index}

The biodiversities of fungi in different soils were evaluated by the Shannon-Wiener index (SWI). SWIs were calculated based on the formula SWI $=-\sum_{i}^{S}(\mathrm{Pi})(\ln P i)$, where $s$ is the total number of species in the sample, $i$ is the total number of individuals in one species, $P i$ is the proportion of species I in the sample, $\ln P i$ is the value of the natural logarithm of $P i$ [47].

\subsection{Bioassay of the Fungal Strains on the B-Biotype Whitefly}

The isolates of rare fungal species were subject to a bioassay against the B-biotype whitefly (Bemisia tabaci) based on the reference [8]. Summarily, the fungal conidia suspensions of $1.0 \times 10^{8}$ spores $/ \mathrm{mL}$ were prepared with a $0.02 \%$ Tween- 80 solution. The population of the B-biotype whiteflies used in this study was a greenhouse population reared for $>20$ generations. Hibiscus rosa-sinensis was cultured in cages to feed the insects. The second instar nymphs were selected for the bioassay based on the leaf immersion method (China standard NY/T 1154.1 4-2008). In brief, the H. rosa-sinensis leaves with second instar whitefly nymphs were dipped into conidial suspension for $20 \mathrm{~s}$. The pest's numbers were surveyed each $24 \mathrm{~h}$ after treatment. The nymphs were considered as diseased death when they lost their normal yellow-green color, turgidity, and smooth cuticle structure, and subsequently mildew grown. The $0.02 \%$ Tween- 80 solution was used as a control group. The experiment was replicated three times. The accumulated mortalities (\%) were subjected to an analysis of DMRT (Duncan's multiple range test) by using DPS 9.5 (Data Processing System, Zhejiang, China) [48].

\section{Results}

\subsection{Entomopathogenic Fungi Species Diversity in Soils of South China}

The total of 292 fungal isolates were purified. Among them, 213 EF isolates were identified as 19 species that belong to 12 genera according to the morphological and molecular analysis. Purpureocillium lilacinum with 75 isolates was the richest species, but the congeneric species P. lavendulum had only two isolates (Figure 2, Table S1). The genus Metarhizium had four species, M. anisopliae, M. flavoviride, M. marquandii, and M. carneum, which 26, 4, 15 and 11 isolates were respectively obtained (Figure 2, Table S1). The genus Isaria had four species including I. cateniannulata, I. farinosa, I. fumosorosea, and I. javanica with 1, 1,2 and 29 isolates (Figure 3, Table S1). The genus Beauveria had only one species B. bassiana with 26 isolates (Figure 3, Table S1). Both the Pochonia chlamydosporia and its close species Metapochonia bulbillosa all had 7 isolates (Figure 4, Table S1). Other species with 1-3 isolates were respectively identified as Nectria mauritiicola, Scopulariopsis brumptii, Clonostachys sp., Lecanicillium psalliotae, Phialophora verrucosa, Simplicillium lanosoniveum, Cephalotrichum microsporum, Penicillium citrinum, Schizophyllum commune, Talaromyces pinophilus, and Umbelopsis dimorpha, in which the last five species have not been entomopathogenic fungi (Figure 4, Table S1). The other 71 isolates were not 
classified yet. Obviously, P. lilacinum, I. javanica, B. bassiana, and M. anisopliae were the most abundant EFs species.

A

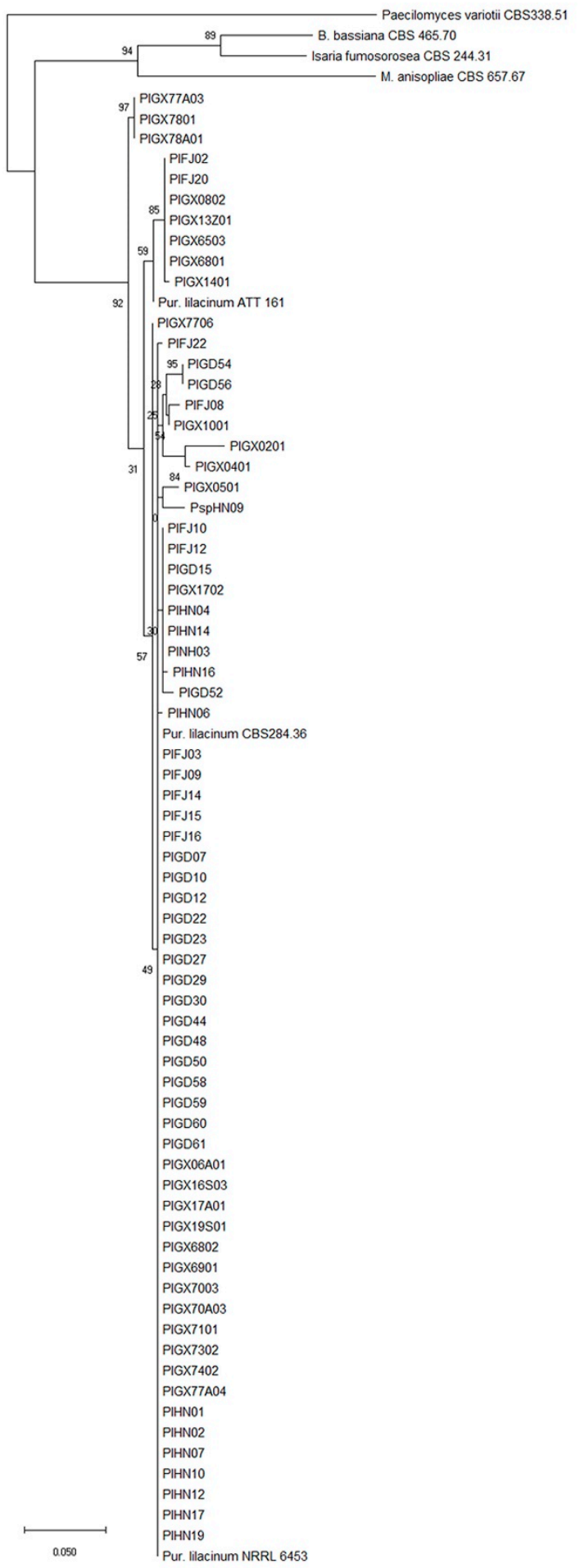

B

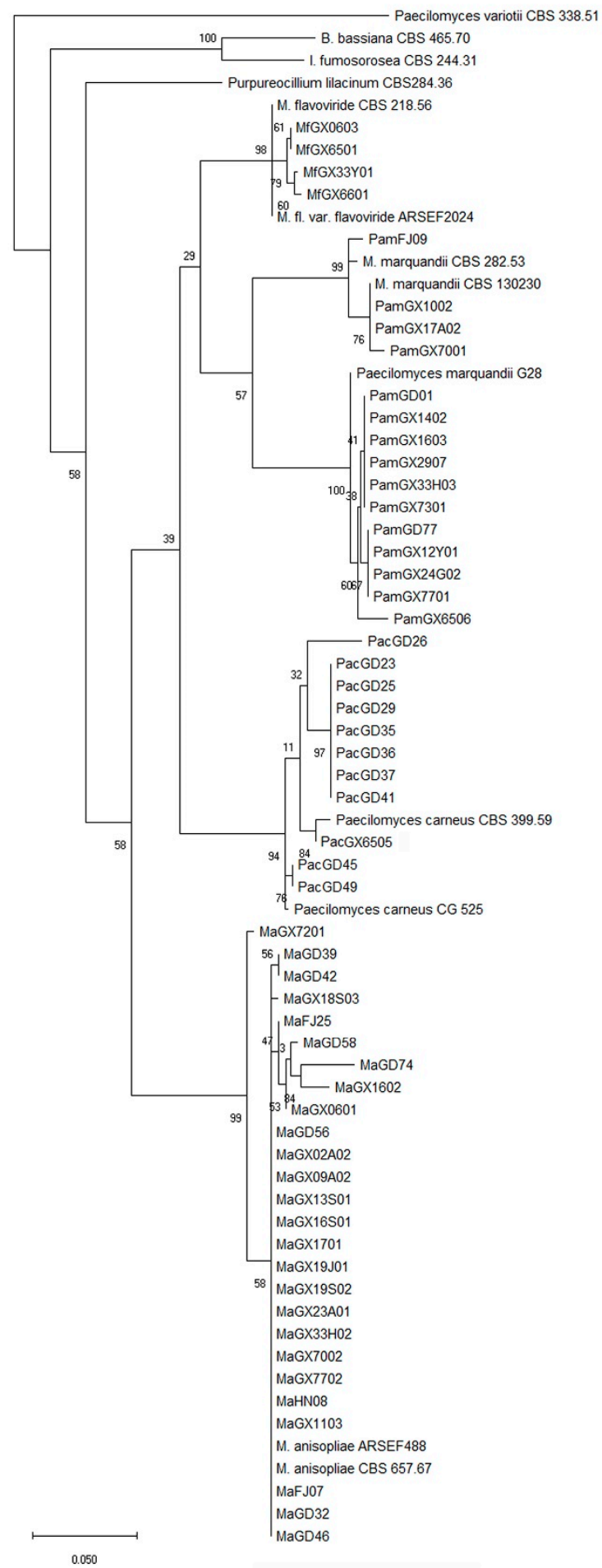

Figure 2. Phylogenetic tree of Purpureocillium spp. (A) and Metarhizium spp. (B) isolates. 


\section{A}

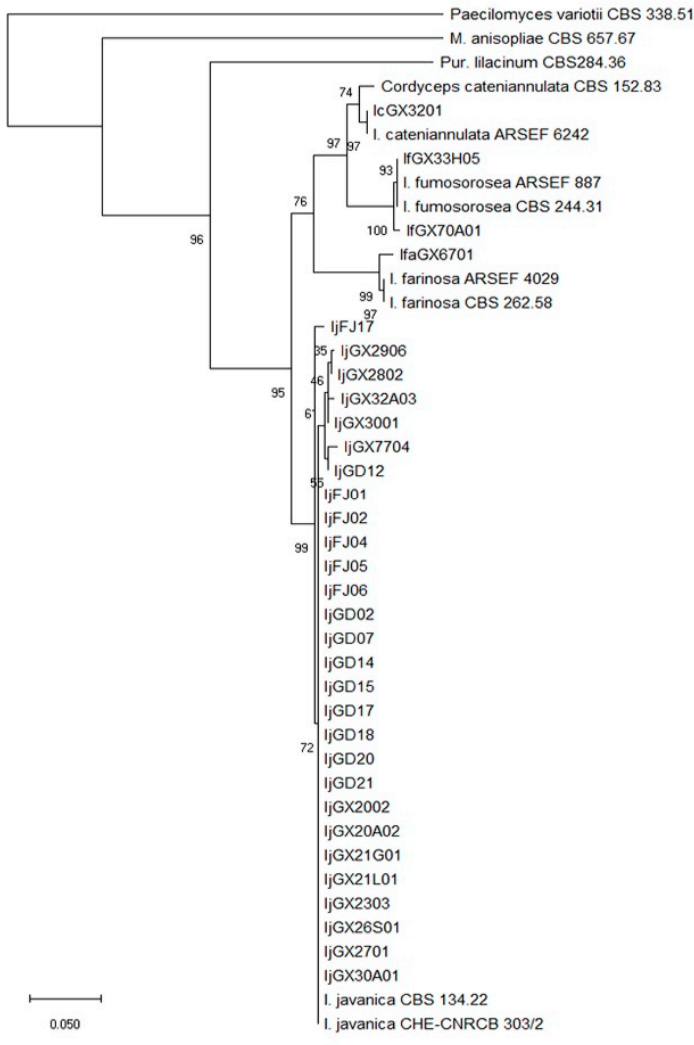

B

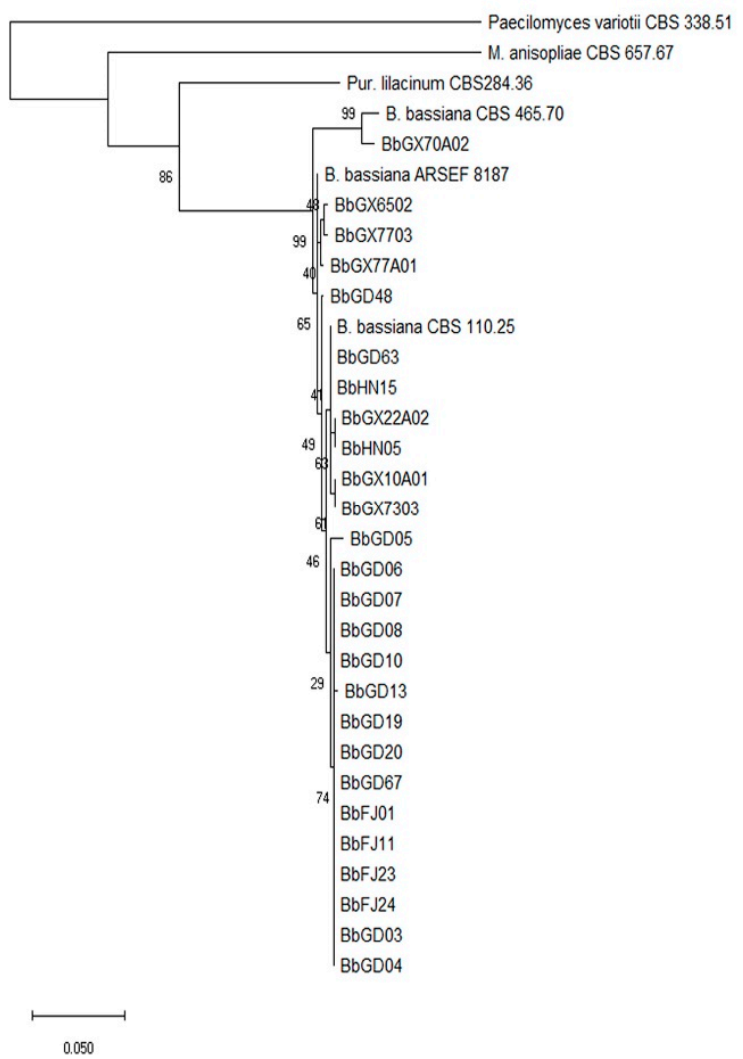

Figure 3. Phylogenetic tree of the Isaria spp. (A) and Beauveria bassiana (B) isolates.

A

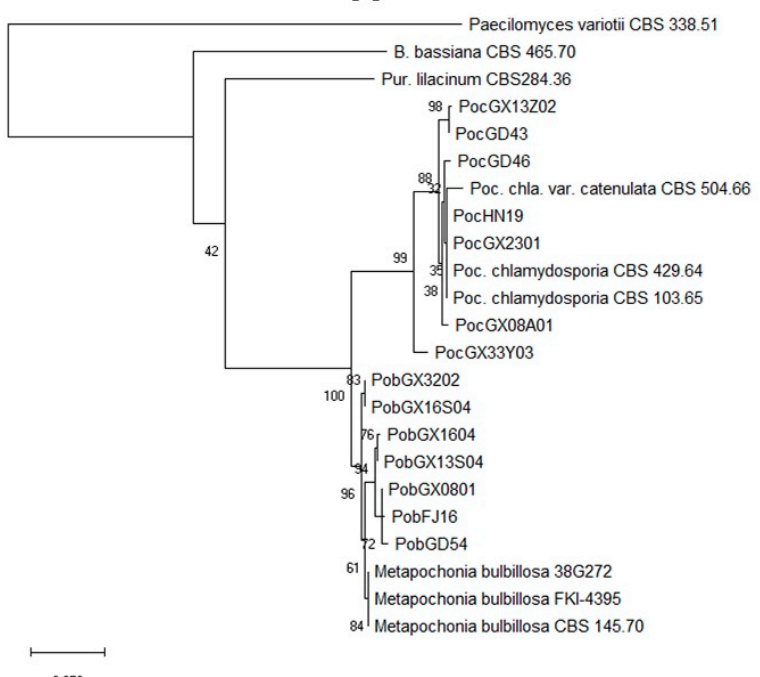

B

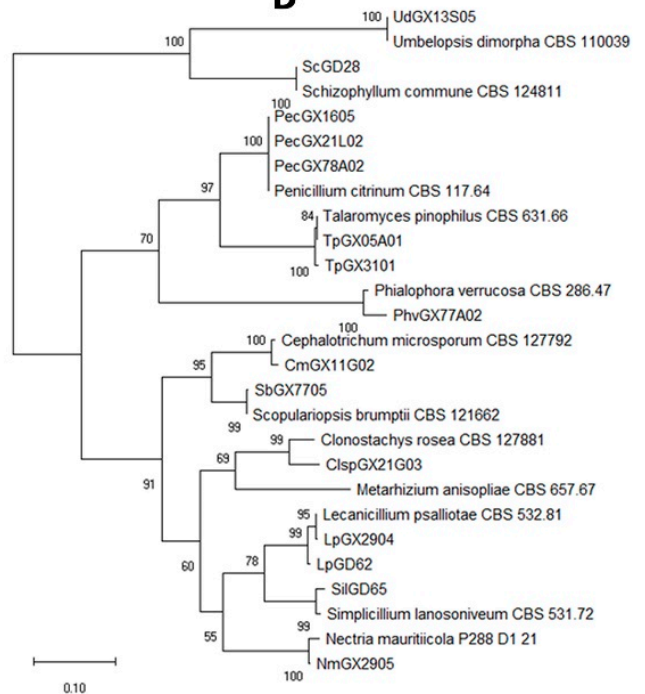

Figure 4. Phylogenetic tree of the Pochonia/Metapochonia spp. (A) and other (B) isolates.

\subsection{The Distribution of Soil EFs in Different Areas of South China}

There were different numbers and isolating rates of EFs in various areas of South China. Compared with the average fungal isolating rates of $88.89 \%$ and $75.76 \%$ in all the fungi and EFs samples, Hainan had the highest rates of $>90 \%$ (Table 2). However, the Shannon-Wiener index indicated that Hainan was the lowest EFs biodiversity district, while Guangxi had the best EFs biodiversity with a SWI of 2.29. Guangdong and Fujian had the SWI 1.4-1.9 (Table 2). 
Table 2. The fungi isolation and biodiversity of different regions.

\begin{tabular}{|c|c|c|c|c|c|c|c|c|c|}
\hline \multirow{2}{*}{ Region } & \multicolumn{3}{|c|}{ Sample Numbers } & \multicolumn{2}{|c|}{ Isolation Rate (\%) } & \multicolumn{2}{|c|}{ Isolate Number } & \multirow{2}{*}{$\begin{array}{c}\text { EF } \\
\text { Species }\end{array}$} & \multirow{2}{*}{$\begin{array}{c}\text { Shannon } \\
\text { Wiener Index }\end{array}$} \\
\hline & Total & Fungi & EFs & Fungi & EFs & Total & EFs & & \\
\hline Fujian & 26 & 21 & 21 & 80.77 & 80.77 & 27 & 27 & 6 & 1.43 \\
\hline Guangdong & 78 & 68 & 55 & 87.18 & 70.51 & 85 & 68 & 10 & 1.86 \\
\hline Guangxi & 75 & 69 & 56 & 92.00 & 74.67 & 160 & 99 & 18 & 2.29 \\
\hline Hainan & 19 & 18 & 18 & 94.74 & 94.74 & 20 & 19 & 4 & 0.73 \\
\hline Total & 198 & 176 & 150 & 88.89 * & $75.76^{*}$ & 292 & 213 & 19 & \\
\hline
\end{tabular}

\subsection{The Biodiversity of Soil EFs in Different Samples Environments}

There were different numbers and isolating rates of EFs in various areas of South China. Compared with the average fungal isolating rates of $88.89 \%$ and $75.76 \%$ in all the fungi and EFs samples, grass and orchard samples had the larger fungal rates of $>95 \%$, while the crop and orchard samples had higher EFs rates of $>80 \%$ (Table 3). However, the Shannon-Wiener index indicated that the orchard and fallow land had the lowest EFs biodiversity with the SWI of 1.52, while the grass samples had the best EFs biodiversity with a SWI of 2.14. Crop, eucalyptus, and forest had the SWI 1.8-2.0 (Table 3).

Table 3. The fungi isolation and biodiversity of different samples.

\begin{tabular}{cccccccccc}
\hline \multirow{2}{*}{$\begin{array}{c}\text { Sample } \\
\text { Vegetation }\end{array}$} & \multicolumn{3}{c}{ Sample Numbers } & \multicolumn{2}{c}{ Isolation Rate (\%) } & Isolate Number & \multirow{2}{*}{$\begin{array}{c}\text { EF } \\
\text { Species }\end{array}$} & $\begin{array}{c}\text { Shannon-Wiener } \\
\text { Index }\end{array}$ \\
\cline { 2 - 7 } & Total & Fungi & EFs & Fungi & EFs & Total & EFs & \\
\hline Crop & 48 & 43 & 41 & 89.58 & 85.42 & 58 & 51 & 11 & 1.89 \\
Eucalyptus & 30 & 23 & 19 & 76.67 & 63.33 & 41 & 26 & 9 & 1.93 \\
Fallowland & 32 & 28 & 25 & 87.50 & 78.13 & 37 & 32 & 7 & 1.52 \\
Forest & 32 & 28 & 24 & 87.50 & 75.00 & 53 & 38 & 12 & 1.97 \\
Grass & 44 & 42 & 31 & 95.45 & 70.45 & 83 & 53 & 14 & 2.14 \\
Orchard & 12 & 12 & 10 & 100 & 83.33 & 20 & 13 & 5 & 1.52 \\
Total & 198 & 176 & 150 & $88.89 *$ & $75.76 *$ & 292 & 213 & 19 & \\
\hline \multicolumn{8}{c}{ * The means of isolation rate $(\%)$ in all sample vegetation. }
\end{tabular}

\subsection{The Pathogenicities of Fungal Isolates against B-Biotype Whitefly}

The 15 isolates were subjected to the bioassay against a B-biotype whitefly of second instar nymphs. The results indicated that the four isolates, CmGX11G02 of Cephalotrichum microsporum, PecGX1605 of Penicillium citrinum, TpGX05A01 of Talaromyces pinophilus, and UdGX13S05 of Umbelopsis dimorpha, were not effective to the whitefly, because they gave the insignificant mortalities (no different from the control) $(p<0.05)$ to the insect (Table 4). However, the other 11 isolates all had substantial pathogenic activities to the whitefly (Table 4). Additionally, it was first found that Nectria mauritiicola and Scopulariopsis brumptii had the entomopathogenic activities. In addition, the symptoms of disease insects usually become brown, black colors and not shiny on the surface, finally, the EFs hyphae grown out of the dead body (Figure 5).

Table 4. The pathogenicities of fungal isolates against the second nymphs of the B-biotype whitefly.

\begin{tabular}{llcccc}
\hline \multirow{2}{*}{ Isolate } & Species & \multicolumn{3}{c}{ Accumulated Mortality (\%) * on Post-Treatment Days } \\
\cline { 2 - 5 } & & 4 Days & 6 Days & 8 Days & 10 Days \\
\hline BbGD07 & Beauveria bassiana & $27.64 \pm 5.32 \mathrm{a}$ & $33.67 \pm 4.69 \mathrm{a}$ & $39.9 \pm 5.48 \mathrm{a}$ & $55.56 \pm 7.89 \mathrm{c}$ \\
IfFJ05 & Isaria javanica & $6.94 \pm 2.13 \mathrm{~d}$ & $17.87 \pm 2.23 \mathrm{c}$ & $42.68 \pm 1.87 \mathrm{a}$ & $61.03 \pm 3.08 \mathrm{a}$ \\
LpGD62 & Lecanicillium psalliotae & $8.19 \pm 3.15 \mathrm{c}$ & $12.33 \pm 1.96 \mathrm{c}$ & $39.40 \pm 4.32 \mathrm{a}$ & $66.19 \pm 8.25 \mathrm{a}$ \\
ClspGX21G03 & Clonostachys sp. & $12.67 \pm 3.06 \mathrm{~b}$ & $22.17 \pm 2.34 \mathrm{~b}$ & $35.06 \pm 3.16 \mathrm{~b}$ & $44.04 \pm 4.15 \mathrm{~d}$ \\
MaFJ07 & Metarhizium anisopliae & $8.15 \pm 3.18 \mathrm{c}$ & $13.11 \pm 4.98 \mathrm{c}$ & $44.41 \pm 8.08 \mathrm{a}$ & $61.02 \pm 5.33 \mathrm{a}$ \\
NmGX2905 & Nectria mauritiicola & $6.00 \pm 2.00 \mathrm{~d}$ & $16.75 \pm 4.06 \mathrm{c}$ & $27.46 \pm 5.48 \mathrm{c}$ & $35.75 \pm 7.47 \mathrm{e}$ \\
PamGD01 & Paecilomyces marquandii & $8.31 \pm 3.22 \mathrm{c}$ & $20.88 \pm 6.48 \mathrm{~b}$ & $46.53 \pm 0.42 \mathrm{a}$ & $65.97 \pm 2.99 \mathrm{a}$ \\
\hline
\end{tabular}


Table 4. Cont.

\begin{tabular}{llcccc}
\hline \multirow{2}{*}{ Isolate } & \multirow{2}{*}{ Species } & \multicolumn{3}{c}{ Accumulated Mortality (\%) * on Post-Treatment Days } \\
\cline { 2 - 5 } & & 4 Days & 6 Days & 8 Days & 10 Days \\
\hline PhvGX77A02 & Phialophora verrucosa & $9.00 \pm 3.83 \mathrm{c}$ & $16.75 \pm 3.71 \mathrm{c}$ & $28.5 \pm 5.21 \mathrm{c}$ & $38.34 \pm 5.45 \mathrm{e}$ \\
PlHN01 & Purpureocillium lilacinum & $10.26 \pm 3.37 \mathrm{bc}$ & $16.46 \pm 2.71 \mathrm{c}$ & $40.29 \pm 3.13 \mathrm{a}$ & $58.69 \pm 3.51 \mathrm{~b}$ \\
PocGD43 & Pochonia chlamydosporia & $7.89 \pm 2.56 \mathrm{~cd}$ & $15.75 \pm 1.38 \mathrm{c}$ & $44.78 \pm 2.01 \mathrm{a}$ & $64.40 \pm 1.87 \mathrm{a}$ \\
SbGX7705 & Scopulariopsis brumptii & $8.00 \pm 3.65 \mathrm{c}$ & $14.72 \pm 3.71 \mathrm{c}$ & $22.8 \pm 4.27 \mathrm{c}$ & $29.02 \pm 3.54 \mathrm{f}$ \\
CmGX11G02 & Cephalotrichum microsporum & $1.32 \pm 0.45 \mathrm{e}$ & $3.15 \pm 0.46 \mathrm{~d}$ & $4.25 \pm 0.39 \mathrm{~d}$ & $4.75 \pm 0.40 \mathrm{~g}$ \\
PecGX1605 & Penicillium citrinum & $1.18 \pm 0.45 \mathrm{e}$ & $2.57 \pm 0.41 \mathrm{~d}$ & $3.79 \pm 0.32 \mathrm{~d}$ & $4.11 \pm 0.33 \mathrm{~g}$ \\
TpGX05A01 & Talaromyces pinophilus & $1.26 \pm 0.31 \mathrm{e}$ & $2.67 \pm 0.37 \mathrm{~d}$ & $3.91 \pm 0.38 \mathrm{~d}$ & $4.08 \pm 0.34 \mathrm{~g}$ \\
UdGX13S05 & Umbelopsis dimorpha & $1.31 \pm 0.42 \mathrm{e}$ & $2.78 \pm 0.41 \mathrm{~d}$ & $3.79 \pm 0.32 \mathrm{~d}$ & $3.92 \pm 0.31 \mathrm{~g}$ \\
& Control & $1.25 \pm 0.55 \mathrm{e}$ & $2.50 \pm 0.50 \mathrm{~d}$ & $3.50 \pm 0.41 \mathrm{~d}$ & $3.75 \pm 0.38 \mathrm{~g}$ \\
\hline
\end{tabular}

* The mean \pm SE at the days post-treatment, the different letters behind indicate the significant difference $(p<0.05)$ by DMRT (Duncan's multiple range test).
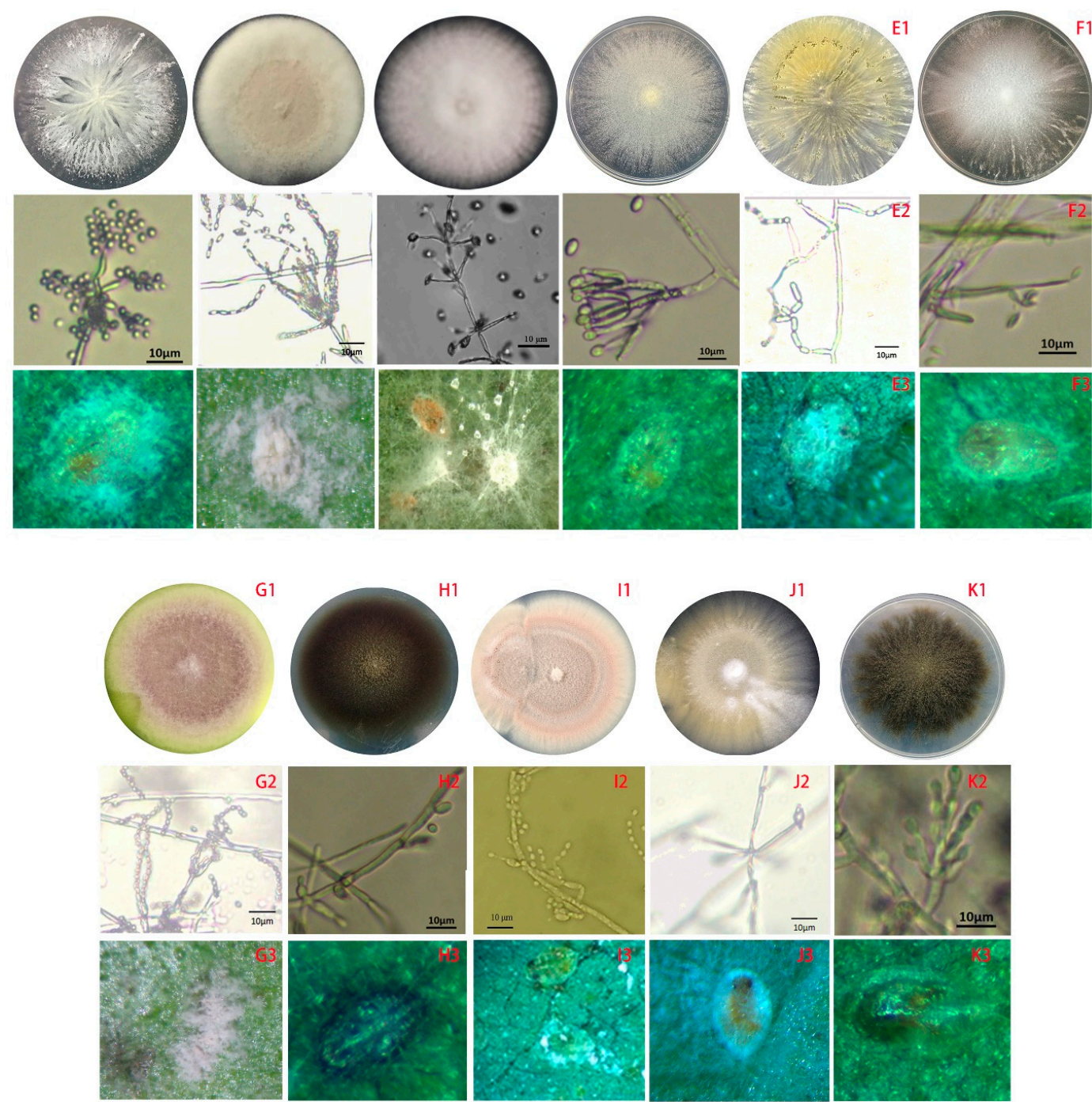

Figure 5. The feature profiles of entomopathogenic fungi (EFs) and the symptoms of whiteflies infected by different isolates. A, BbGD07 of Beauveria bassiana; B, IfFJ05 of Isaria fumosorosea; C, LpGD62 of Lecanicillium psalliotae; D, ClspGX21G03 of Clonostachys sp.; E, MaFJ07 of Metarhizium anisopliae; F, NmGX2905 of Nectria mauritiicola; G, PamGD01 of Metarhizium marquandii; H, PhvGX77A02 of Phialophora verrucosa; I, PIHN01 of Purpureocillium lilacinum; J, PocGD43 of Pochonia chlamydosporia; K, SbGX7705 of Scopulariopsis brumptii; 1, colony; 2, conidial structure; 3, symptoms of whiteflies. Bar $=10 \mu \mathrm{m}$. 


\section{Discussion}

It is difficult to compare and evaluate the biodiversities of the soil EFs, due to the lack of general concepts and reliable approaches to define microbial species, studies on the soil microbial communities concentrate on genetic diversity and functional diversity more than the species diversity [49]. To investigate the soil EFs, it is necessary to employ a reliable approach. Traditionally, the Galleria mellonella (greater wax moth) bait is a common tool for the EFs isolation from soil. However, it needs more consumption of work and times, while probably some strains (for example, those non-pathogens to the great wax moth) could be not obtained $[17,50]$. Then, the metagenome has been developing for diversity research of soil microbes in the recent decade [51], it can detect the soil EFs species, but it cannot isolate the EFs strain and discover new EFs species. In addition, selective media with the advantages of more simple and economical technology have been using to separate the soil EFs [52].

Here, we investigated the EFs distribution in a larger scale of South China by using a selective medium. Undoubtedly, our results first provide a great deal of information of the soil EF species and strains in these areas. The author's group has been using the selective medium to obtain many EFs in recent years [8], we think that many factors influence the EFs isolation in practice. First, it is difficult to isolate the EFs from the too wet soil, because high moisture seriously affects the EFs survival in soil [14]. Second, the stored-stage of the soil sample is very important as well. Generally, the stored-stage of six months at $0{ }^{\circ} \mathrm{C}$ does not influence the EFs isolation of the soil samples, but if conserved for a longer time, the EFs in the samples will quickly decrease. In addition, the soil samples numbers or the density of the sample collection changes the statistic results of the EFs numbers in an area. In this study, Hainan with less EF isolates might be related to the smaller soil samples and in the rain collected.

Moreover, the result data indicated that the soil environment (vegetation) closely impacts the EFs distribution. Compared to grass and forest samples, the orchard and fallow land samples had less EFs. It might be because there are poorer species of plants and insects and more farming activity in the orchard and fallow land, which might affect the EFs diversity. In fact, among so many farming factors, the fungicides utilization is probably the most important reason to reduce the EFs in the soil. China is a big pesticides consumer, a large number of broad-spectrum fungicide such as carbendazim, chlorothalonil, cancozeb, and azoxystrobin, etc., were sprayed in fields every year, which probably prohibit fungi in the soil [53-55]. However, crop samples had a better EFs diversity than the orchard and fallow land samples, it is maybe related to the cropland that had more plants and insects species, because crops include so many vegetables, grains, etc., but the orchard of South China are mainly Litch, Longan, banana, and mango, etc.

Interestingly, eucalyptus seems not to affect the EFs diversity. Eucalyptus is well-known as an effective reforestation tree species, due to its fast growth and high adaptability to various environmental conditions. However, the introduction of eucalyptus had negative effects such as soil degradation, decline of the ground water level, and decrease of biodiversity [56]. Eucalyptus has a strong allelopathy to inhibit other plants and some soil microorganisms [57], but their effects on the EFs have not been reported yet. The relationship of the EFs and eucalyptus is worthy of further research.

Purpureocillium is a new genus constructed from Paecilomyces lilacinus [44]. Purpureocillium lilacinum is a combination with obvious intraspecific diversity. Many strains of the species have been used as biocontrol agents of phytopathogenic nematodes [58,59], while some strains have insecticidal potency [60] and some others have the risks to cause infection in immunocompromised humans [61,62]. In this experiment, $P$. lilacinum is also the most abundant species isolated from whole six regions with the most 75 isolates, in which the differentiation of the species is found from the phylogenetic tree constructed with these isolates. It is believed that more Purpureocillium species will be discovered in the future. The prevalence of the Purpureocillium fungi in the soil is probably due to intraspecific genetic diversity, extensive uses, and the mass occurrence of the plant root knot nematode disease [63]. However, the similar species, $P$. lavendulum had only two isolates found in this experiment. The reason might be related to the fact that $P$. lavendulum cannot grow at $35^{\circ} \mathrm{C}$ [64], which probably influence its distribution in the hot areas of South China. 
B. bassiana and M. anisopliae are famous EFs species that infect a lot of insects. The two EFs have been used as biocontrol agents for a long time, which is maybe beneficial to their accumulation in soil [65-67]. Therefore, the two EFs were isolated from whole regions in this experiment. M. marquandii and M. carneus were originally classified to the genus Paecilomyces, they were often found in soil $[8,67,68]$.

The genus Isaria was revised from the genus Paecilomyces in 2005, in fact, they have similar morphological features and are very close in phylogeny [29], but many species of Isaria have their sexual name as Cordyceps [69]. I. javanica and I. fumosorosea were the very common EF species extensively used for myco-insecticide to control the aphids, whiteflies, etc., in the world. So, they should be found easily from natural environments [70,71].

Several species isolated in this research were not reported as EFs, so we carried on the bioassay experiment. Nectria mauritiicola and Scopulariopsis brumptii were found as the pathogenicity to whitefly, although their bioactivity were not very strong. If they have the potential used as biocontrol agents need further research. The other four species, Cephalotrichum microsporum, Penicillium citrinum, Talaromyces pinophilus, and Umbelopsis dimorpha, were validated for their non-pathogenicity to whitefly. Although they have not been reported as EFs, but whether they are pathogenic to more other insects needs further researches to confirm.

In conclusion, $213 \mathrm{EFs}$ isolates were identified from a total of 292 isolates in the South China soil. Among them, P. lilacinum was absolutely the dominant EF species, while M. anisopliae, I. javanica, B. bassiana, M. marquandii, and M. carneus were the abundant species. The data results suggested that the Guangxi region, grass, and forest environments have the best EFs diversity. Moreover, the distribution of the EFs in the fallow land and orchard samples were decreased, which implied that the plants and insects diversity on the ground and farming activity such as fungicides spray are likely to affect the EFs diversity. Finally, it was first reported that Nectria mauritiicola and Scopulariopsis brumptii had the entomopathogenic activities to whitefly. The current research will give new insights to the understanding of EFs distribution characteristics and their biodiversities conservation.

Supplementary Materials: The following are available online at http://www.mdpi.com/2076-2607/7/9/311/s1, Table S1: Information of the sites soil samples collected and fungi isolation and identification.

Author Contributions: X.N., J.Z., and W.X. completed most of the experiments including collection of the soil samples, isolation, and identification of fungi strains, bioassay, and data analysis. Q.H. designed the experiments, collected the partial soil samples, and wrote the paper.

Funding: This project was supported by the Guangdong Province Science and Technology Project (2016B020234005) and National Natural Science Foundation of China (31572053).

Conflicts of Interest: The authors declare no conflict of interest.

\section{References}

1. de Faria, M.R.; Wraight, S.P. Mycoinsecticides and mycoacaricides: A comprehensive list with worldwide coverage and international classification of formulation types. Biol. Control 2007, 43, 237-256. [CrossRef]

2. Fang, W.G.; Lu, H.L.; King, G.F.; St Leger, R.J. Construction of a hypervirulent and specific mycoinsecticide for locust control. Sci. Rep. 2014, 4. [CrossRef] [PubMed]

3. Edgington, S.; Moore, D.; El Bouhssini, M.; Sayyadi, Z. Beauveria bassiana for the control of Sunn Pest (Eurygaster integriceps) (Hemiptera: Scutelleridae) and aspects of the insect's daily activity relevant to a mycoinsecticide. Biocontrol Sci. Technol. 2007, 17, 63-79. [CrossRef]

4. Liu, H.; Cao, D.Y.; Liu, H.; Liu, X.H.; Mai, W.L.; Lan, H.T.; Huo, W.; Zheng, Q. The herbal medicine Cordyceps sinensis protects pancreatic beta cells from streptozotocin-induced endoplasmic reticulum stress. Can. J. Diabetes 2016, 40, 329-335. [CrossRef] [PubMed]

5. Cui, J.D. Biotechnological production and applications of Cordyceps militaris, a valued traditional Chinese medicine. Crit. Rev. Biotechnol. 2015, 35, 475-484. [CrossRef]

6. Hu, Q.B.; Li, F.X.; Zhang, Y.P. Risks of mycotoxins from mycoinsecticides to humans. BioMed Res. Int. 2016, 2016, 1-13. [CrossRef]

7. Willis, K.J. (Ed.) State of the World's Fungi 2018; Report; Royal Botanic Gardens, Kew: London, UK, 2018. 
8. Dong, T.Y.; Zhang, B.W.; Jiang, Y.F.; Hu, Q.B. Isolation and classification of fungal whitefly entomopathogens from soils of Qinghai-Tibet Plateau and Gansu Corridor in China. PLoS ONE 2016, 11. [CrossRef]

9. Fisher, J.J.; Rehner, S.A.; Bruck, D.J. Diversity of rhizosphere associated entomopathogenic fungi of perennial herbs, shrubs and coniferous trees. J. Invertebr. Pathol. 2011, 106, 289-295. [CrossRef]

10. Li, Z.L.; Li, X.Q.; Yang, S.Y. Edaphic factor that affect the activity of entomopathogenic fungus Metarhizium anisopliae. Biotechnol. Bull. 2014, 41-46. [CrossRef]

11. Fan, M.Z.; Li, J.Q.; Guo, C.; Hashan, E. Persistent forms and survival potential of Metarhizium anisopliae in soil. J. Northwest. Coll. For. 1991, 6, 48-54.

12. Li, Y.; Hu, Z.L.; Hu, Z.X.; Xiao, H.Y.; Li, H.P. Survival dynamics of Beauveria bassiana Bb09in the muscardine cadaver of Hyphantria cunea and surrounding soil. For. Ecol. Sci. 2018, 33, 172-177. [CrossRef]

13. Zhang, Y.B.; Wu, X.S.; Ye, B.H.; Wang, H.J.; Shu, J.P. Inhibition effects of soil bacteria on conidium germination of Metarhizium pingshaense. Chin. J. Biol. Control 2017, 33, 788-795. [CrossRef]

14. Wu, X.S.; Zhang, Y.B.; Wu, P.P.; Ye, B.H.; Wang, H.J.; Shu, J.P. Influence of temperature, moisture, and soil type on conidium germination of Metarhizium pingshaense in soil. Chin. J. Biol. Control 2014, 30, 766-771. [CrossRef]

15. Keiblinger, K.M.; Schneider, M.; Gorfer, M.; Paumann, M.; Deltedesco, E.; Berger, H.; Jochlinger, L.; Mentler, A.; Zechmeister-Boltenstern, S.; Soja, G.; et al. Assessment of $\mathrm{Cu}$ applications in two contrasting soils-effects on soil microbial activity and the fungal community structure. Ecotoxicology 2018, 27, 217-233. [CrossRef] [PubMed]

16. Chen, Q.L.; Yang, B.S.; Wang, H.; He, F.; Gao, Y.C.; Scheel, R.A. Soil microbial community toxic response to atrazine and its residues under atrazine and lead contamination. Environ. Sci. Pollut. Res. Int. 2015, 22, 996-1007. [CrossRef] [PubMed]

17. Meyling, N.V.; Eilenberg, J. Occurrence and distribution of soil borne entomopathogenic fungi within a single organic agroecosystem. Agric. Ecosyst. Environ. 2006, 113, 336-341. [CrossRef]

18. Masoudi, A.; Koprowski, J.L.; Bhattarai, U.R.; Wang, D. Elevational distribution and morphological attributes of the entomopathogenic fungi from forests of the Qinling mountains in China. Appl. Microbiol. Biotechnol. 2018, 102, 1483-1499. [CrossRef]

19. Skinner, M.; Parker, B.L.; Kim, J.S. Chapter 10-Role of entomopathogenic fungi in integrated pest management. In Integrated Pest Management; Abrol, D.P., Ed.; Academic Press: San Diego, CA, USA, 2014; pp. 169-191.

20. Naruse, T.; Chia, J.E.; Zhou, X. Biodiversity surveys reveal eight new species of freshwater crabs (Decapoda: Brachyura: Potamidae) from Yunnan Province, China. PeerJ 2018, 6, e5497. [CrossRef]

21. Zhao, Q.G.; Huang, G.Q.; Wang, L.X. Forest ecosystems in the south China: Functions, problems and countermeasures. J. For. Environ. 2015, 35, 289-296. [CrossRef]

22. Hu, Q.B.; Ren, S.X.; Wu, J.H.; Chang, J.M.; Musa, P.D. Investigation of destruxin A and B from 80 Metarhizium strains in China, and the optimization of cultural conditions for the strain MaQ10. Toxicon 2006, 48, 491-498. [CrossRef]

23. Kumar, S.; Stecher, G.; Li, M.; Knyaz, C.; Tamura, K. MEGA X: Molecular evolutionary genetics analysis across computing platforms. Mol. Biol. Evol. 2018, 35, 1547-1549. [CrossRef] [PubMed]

24. Johny, S.; Kyei-Poku, G.; Gauthier, D.; van Frankenhuyzen, K.; Krell, P.J. Characterization and virulence of Beauveria spp. recovered from emerald ash borer in southwestern Ontario, Canada. J. Invertebr. Pathol. 2012, 111, 41-49. [CrossRef] [PubMed]

25. Vu, D.; Groenewald, M.; de Vries, M.; Gehrmann, T.; Stielow, B.; Eberhardt, U.; Al-Hatmi, A.; Groenewald, J.Z.; Cardinali, G.; Houbraken, J.; et al. Large-scale generation and analysis of filamentous fungal DNA barcodes boosts coverage for kingdom fungi and reveals thresholds for fungal species and higher taxon delimitation. Stud. Mycol. 2019, 92, 135-154. [CrossRef] [PubMed]

26. Schoch, C.L.; Robbertse, B.; Robert, V.; Vu, D.; Cardinali, G.; Irinyi, L.; Meyer, W.; Nilsson, R.H.; Hughes, K.; Miller, A.N.; et al. Finding needles in haystacks: Linking scientific names, reference specimens and molecular data for Fungi. Database 2014. [CrossRef] [PubMed]

27. Humber, R.A.; Rocha, L.F.N.; Inglis, P.W.; Kipnis, A.; Luz, C. Morphology and molecular taxonomy of Evlachovaea-like fungi, and the status of this unusual conidial genus. Fungal Biol. 2013, 117, 1-12. [CrossRef] [PubMed] 
28. Rehner, S.A.; Minnis, A.M.; Sung, G.H.; Luangsa-ard, J.J.; Devotto, L.; Humber, R.A. Phylogeny and systematics of the anamorphic, entomopathogenic genus Beauveria. Mycologia 2011, 103, 1055-1073. [CrossRef] [PubMed]

29. Luangsa-ard, J.J.; Hywel-Jones, N.L.; Manoch, L.; Samson, R.A. On the relationships of Paecilomyces sect. Isarioidea species. Mycol. Res. 2005, 109. [CrossRef]

30. Inglis, P.W.; Tigano, M.S. Identification and taxonomy of some entomopathogenic Paecilomyces spp. (Ascomycota) isolates using rDNA-ITS sequences. Genet. Mol. Biol. 2006, 29, 132-136. [CrossRef]

31. Cabanillas, H.E.; de Leon, J.H.; Humber, R.A.; Murray, K.D.; Jones, W.A. Isaria poprawskii sp nov (Hypocreales: Cordycipitaceae), a new entomopathogenic fungus from Texas affecting sweet potato whitefly. Mycoscience 2013, 54, 158-169. [CrossRef]

32. Ayala-Zermeno, M.A.; Gallou, A.; Berlanga-Padilla, A.M.; Serna-Dominguez, M.G.; Arredondo-Bernal, H.C.; Montesinos-Matias, R. Characterisation of entomopathogenic fungi used in the biological control programme of Diaphorina citri in Mexico. Biocontrol Sci. Technol. 2015, 25, 1192-1207. [CrossRef]

33. Kepler, R.M.; Sung, G.H.; Ban, S.; Nakagiri, A.; Chen, M.J.; Huang, B.; Li, Z.; Spatafora, J.W. New teleomorph combinations in the entomopathogenic genus Metacordyceps. Mycologia 2012, 104, 182-197. [CrossRef] [PubMed]

34. Enkerli, J.; Ghormade, V.; Oulevey, C.; Widmer, F. PCR-RFLP analysis of chitinase genes enables efficient genotyping of Metarhizium anisopliae var. anisopliae. J. Invertebr. Pathol. 2009, 102, 185-188. [CrossRef] [PubMed]

35. Driver, F.; Milner, R.J.; Trueman, J.W.H. A taxonomic revision of Metarhizium based on a phylogenetic analysis of rDNA sequence data. Mycol. Res. 2000, 104, 134-150. [CrossRef]

36. Koehn, F.E.; Kirsch, D.R.; Feng, X.D.; Janso, J.; Young, M. A cell wall-active lipopeptide from the fungus Pochonia bulbillosa. J. Nat. Prod. 2008, 71, 2045-2048. [CrossRef] [PubMed]

37. Zare, R.; Gams, W.; Culham, A. A revision of Verticillium sect. Prostrata. I. phylogenetic studies using ITS sequences. Nova Hedwig. 2000, 71, 465-480. [CrossRef]

38. Nonaka, K.; Omura, S.; Masuma, R.; Kaifuchi, S.; Masuma, R. Three new Pochonia taxa (Clavicipitaceae) from soils in Japan. Mycologia 2013, 105, 1202-1218. [CrossRef] [PubMed]

39. Ellouze, W.; Hamel, C.; Vujanovic, V.; Gan, Y.T.; Bouzid, S.; St-Arnaud, M. Chickpea genotypes shape the soil microbiome and affect the establishment of the subsequent durum wheat crop in the semiarid North American Great Plains. Soil Biol. Biochem. 2013, 63, 129-141. [CrossRef]

40. Bukovska, P.; Jelinkova, M.; Hrselova, H.; Sykorova, Z.; Gryndler, M. Terminal restriction fragment length measurement errors are affected mainly by fragment length, $\mathrm{G}+\mathrm{C}$ nucleotide content and secondary structure melting point. J. Microbiol. Methods 2010, 82, 223-228. [CrossRef] [PubMed]

41. Samson, R.A.; Houbraken, J.; Varga, J.; Frisvad, J.C. Polyphasic taxonomy of the heat resistant ascomycete genus Byssochlamys and its Paecilomyces anamorphs. Persoonia 2009, 22, 14-27. [CrossRef]

42. Attili-Angelis, D.; Duarte, A.P.M.; Pagnocca, F.C.; Nagamoto, N.S.; de Vries, M.; Stielow, J.B.; de Hoog, G.S. Novel Phialophora species from leaf-cutting ants (tribe Attini). Fungal Divers. 2014, 65, 65-75. [CrossRef]

43. Rodrigues, A.; Mueller, U.G.; Ishak, H.D.; Bacci, M.J.; Pagnocca, F.C. Ecology of microfungal communities in gardens of fungus-growing ants (Hymenoptera: Formicidae): A year-long survey of three species of attine ants in Central Texas. FEMS Microbiol. Ecol. 2011, 78, 244-255. [CrossRef] [PubMed]

44. Luangsa-Ard, J.; Houbraken, J.; van Doorn, T.; Hong, S.B.; Borman, A.M.; Hywel-Jones, N.L.; Samson, R.A. Purpureocillium, a new genus for the medically important Paecilomyces lilacinus. FEMS Microbiol. Lett. 2011, 321, 141-149. [CrossRef] [PubMed]

45. Jagielski, T.; Sandoval-Denis, M.; Yu, J.; Yao, L.M.; Bakula, Z.; Kalita, J.; Skora, M.; Krzysciak, P.; De Hoog, G.S.; Guarro, J.; et al. Molecular taxonomy of scopulariopsis-like fungi with description of new clinical and environmental species. Fungal Biol. 2016, 120, 586-602. [CrossRef] [PubMed]

46. Wang, Y.N.; Liu, X.Y.; Zheng, R.Y. Umbelopsis changbaiensis sp nov from China and the typification of Mortierella vinacea. Mycol. Prog. 2014, 13, 657-669. [CrossRef]

47. Spellerberg, I.F. Shannon-Wiener Index. Encycl. Ecol. 2008, 3249-3252. [CrossRef]

48. Tang, Q.Y.; Zhang, C.X. Data Processing System (DPS) software with experimental design, statistical analysis and data mining developed for use in entomological research. Insect Sci. 2013, 20, 254-260. [CrossRef] [PubMed] 
49. Deng, H. A review of diversity-stability relationship of soil microbial community: What do we not know? J. Environ. Sci. 2012, 24, 1027-1035. [CrossRef]

50. Ali-Shtayeh, M.S.; Mara'i, A.B.B.M.; Jamous, R.M. Distribution, occurrence and characterization of entomopathogenic fungi in agricultural soil in the Palestinian area. Mycopathologia 2003, 156, 235-244. [CrossRef]

51. Popescu, L.; Cao, Z.P. From microscopy to genomic approach in soil biodiversity assessment. Curr. Issues Mol. Biol. 2018, 27, 195-198. [CrossRef]

52. Shin, T.Y.; Lee, W.W.; Ko, S.H.; Choi, J.B.; Bae, S.M.; Choi, J.Y.; Lee, K.S.; Je, Y.H.; Jin, B.R.; Woo, S.D. Distribution and characterisation of entomopathogenic fungi from Korean soils. Biocontrol Sci. Technol. 2013, 23, 288-304. [CrossRef]

53. Niewiadomska, A.; Sawinska, Z.; Wolna-Maruwka, A. Impact of seed dressings on microbiological activity of soil under Winter Triticale cultivation. Arch. Environ. Prot. 2012, 38, 89-101. [CrossRef]

54. Dung, J.K.S.; Kaur, N.; Walenta, D.L.; Alderman, S.C.; Frost, K.E.; Hamm, P.B. Reducing claviceps purpurea sclerotia germination with soil-applied fungicides. Crop Prot. 2018, 106, 146-149. [CrossRef]

55. Pan, X.W.; Richardson, M.D.; Deng, S.P.; Kremer, R.J.; English, J.T.; Mihail, J.D.; Sams, C.E.; Scharf, P.C.; Veum, K.S.; Xiong, X. Effect of organic amendment and cultural practice on large patch occurrence and soil microbial community. Crop Sci. 2017, 57, 2263-2272. [CrossRef]

56. Ping, L.; Xie, Z.Q. Effects of introducing Eucalyptus on indigenous biodiversity. Chin. J. Appl. Ecol. 2009, 20, 1765-1774.

57. Kikuchi, A.; Yu, X.; Shimazaki, T.; Kawaoka, A.; Ebinuma, H.; Watanabe, K.N. Allelopathy assessments for the environmental biosafety of the salt-tolerant transgenic Eucalyptus camaldulensis, genotypes codA12-5B, codA 12-5C, and codA 20C. J. Wood Sci. 2009, 55, 149-153. [CrossRef]

58. Gine, A.; Sorribas, F.J. Effect of plant resistance and BioAct WG (Purpureocillium lilacinum strain 251) on Meloidogyne incognita in a tomato-cucumber rotation in a greenhouse. Pest Manag. Sci. 2017, 73, 880-887. [CrossRef] [PubMed]

59. Singh, S.; Pandey, R.K.; Goswami, B.K. Bio-control activity of Purpureocillium lilacinum strains in managing root-knot disease of tomato caused by Meloidogyne incognita. Biocontrol Sci. Technol. 2013, 23, 1469-1489. [CrossRef]

60. Medeiros, F.R.; de Lemos, R.N.S.; Rodrigues, A.A.C.; Batista, A.; de Oliveira, L.D.M.G.; Araujo, J.R.G. Occurrence of Purpureocillium lilacinum in citrus black fly nymphs. Rev. Bras. Frutic. 2018, 40. [CrossRef]

61. Saghrouni, F.; Saidi, W.; Ben Said, Z.; Gheith, S.; Ben Said, M.; Ranque, S.; Denguezli, M. Cutaneous hyalohyphomycosis caused by Purpureocillium lilacinum in an immunocompetent patient: Case report and review. Med. Mycol. 2013, 51, 664-668. [CrossRef]

62. Shivaprasad, A.; Ravi, G.C.; Rama, S. A rare case of nasal septal perforation due to Purpureocillium lilacinum: Case report and review. Indian J. Otolaryngol. 2013, 65, 184-188. [CrossRef]

63. Baidoo, R.; Mengistu, T.; McSorley, R.; Stamps, R.H.; Brito, J.; Crow, W.T. Management of Root-knot Nematode (Meloidogyne incognita) on pittosporum tobira under greenhouse, field, and on-farm conditions in Florida. J. Nematol. 2017, 49, 133-139. [CrossRef] [PubMed]

64. Perdomo, H.; Cano, J.; Gené, J.; García, D.; Hernández, M.; Guarro, J. Polyphasic analysis of Purpureocillium lilacinum isolates from different origins and proposal of the new species Purpureocillium lavendulum. Mycologia 2013, 105, 151-161. [CrossRef] [PubMed]

65. Greenfield, M.; Jimenez, M.I.G.; Ortiz, V.; Vega, F.E.; Kramer, M.; Parsa, S. Beauveria bassiana and Metarhizium anisopliae endophytically colonize cassava roots following soil drench inoculation. Biol. Control 2016, 95, 40-48. [CrossRef] [PubMed]

66. Parker, B.L.; Skinner, M.; Gouli, S.Y.; Gouli, V.V.; Tobi, D.; Kim, J.S. Persistence of Beauveria bassiana sensu lato and Metarhizium anisopliae sensu lato in Vermont (USA) forest soil. Biocontrol Sci. Technol. 2015, 25, 768-788. [CrossRef]

67. Meyling, N.V.; Schmidt, N.M.; Eilenberg, J. Occurrence and diversity of fungal entomopathogens in soils of low and high Arctic Greenland. Polar. Biol. 2012, 35, 1439-1445. [CrossRef]

68. Torres-Barragan, A.; Anaya, A.L.; Alatorre, R.; Toriello, C. Entomopathogenic fungi from 'El Eden' Ecological Reserve, Quintana Roo, Mexico. Mycopathologia 2004, 158, 61-71. [CrossRef]

69. Yokoyama, E.; Arakawa, M.; Yamagishi, K.; Hara, A. Phylogenetic and structural analyses of the mating-type loci in Clavicipitaceae. FEMS Microbiol. Lett. 2006, 264, 182-191. [CrossRef] 
70. Zhang, B.W.; Zou, C.H.; Hu, Q.B. Effects of Isaria fumosorosea on TYLCV (Tomato Yellow Leaf Curl Virus) accumulation and transmitting capacity of Bemisia tabaci. PLoS ONE 2016, 11. [CrossRef]

71. Chen, X.R.; Li, L.; Hu, Q.B.; Zhang, B.W.; Wu, W.; Jin, F.L.; Jiang, J.X. Expression of dsRNA in recombinant Isaria fumosorosea strain targets the TLR7 gene in Bemisia tabaci. BMC Biotechnol. 2015, 15. [CrossRef]

(C) 2019 by the authors. Licensee MDPI, Basel, Switzerland. This article is an open access article distributed under the terms and conditions of the Creative Commons Attribution (CC BY) license (http://creativecommons.org/licenses/by/4.0/). 